\section{TINGKAT KERENTANAN MASYARAKAT TERHADAP BENCANA BANJIR DI PERUMNAS TLOGOSARI, KOTA SEMARANG}

\author{
Rizsa Putri Danianti ${ }^{*}$ dan Sariffuddin \\ Jurusan Perencanaan Wilayah dan Kota, \\ Fakultas Teknik, Universitas Diponegoro, Semarang \\ *Email: rizsa.putri15@pwk.undip.ac.id
}

Jurnal Pengembangan Kota (2015) Volume 3 No. 2 (90-99)

Tersedia online di:

http://ejournal2.undip.ac.id/index.php/jpk

\begin{abstract}
Abstrak
Perumnas Tlogosari merupakan salah satu perumahan skala besar di Kota Semarang yang terdampak persoalan ekologi kota, yaitu banjir. Persoalan ekologi ini terjadi bersamaan dengan peningkatan pertumbuhan penduduk sekitar 1,4\% pertahunnya, yang menjadikan pertumbuhan Kota Semarang mengarah pada kondisi rentan. Oleh sebab itu sangat perlu untuk mewujudkan Kota Semarang sebagai kota tangguh dengan melakukan penilaian tingkat kerentanan, karena hasil dari penilaian kerentanan tersebut dapat menjadi tolak ukur pencapaian sebuah kota tangguh. Penelitian ini dilakukan untuk menilai tingkat kerentanan masyarakat di Perumnas Tlogosari dalam menghadapi banjir pada saat siang dan malam. Penilaian kerentanan ini dibedakan berdasarkan waktu, karena ada perbedaan jumlah masyarakat yang berada di rumah pada saat siang dan malam. Penilaian kerentanan dilakukan menggunakan metode kuantitatif dengan teknik analisis skoring pembobotan. Hasil dari penelitian ini menunjukkan bahwa kerentanan siang masyarakat lebih tinggi, dibandingkan kerentanan malam. Hal ini dibuktikan dengan penurunan jumlah masyarakat di kuadran 3 dan 5 pada saat malam, diikuti dengan kenaikan jumlah masyarakat di kuadran 1 dan 2 sebesar 2-3\%. Banyaknya masyarakat yang berada di kuadran 1, 2 dan 3 mengartikan bahwa masyarakat berada pada selang toleransi dari kemampuan mereka dalam menghadapi banjir. Oleh karena itu, masing-masing rumah tangga telah berketahanan dalam menghadapi banjir.
\end{abstract}

Kata Kunci: Banjir, Tingkat kerentanan

\section{PENDAHULUAN}

Tiga tantangan besar perencanaan kota dewasa ini adalah permasalahan ekologi, pesatnya perkembangan teknologi informasi dan transformasi sosial masyarakat (Abdoullaev, 2011). Dari ketiga tantangan itu, persoalan ekologi kota merupakan permasalahan yang saat ini menjadi fokus perhatian para perencana. Adanya permasalahan ekologi berupa perubahan iklim dan bencana dapat mengancam keberlanjutan kota, yang diperkirakan akan terus berkembang mengikuti pertumbuhan penduduknya.

ISSN 2337-7062 @ 2015

This is an open access article under the CC-BY-NC-ND license (http://creativecommons.org/licenses/by-nc-sa/4.0/). - lihat halaman depan (C) 2015

Diterima 10 Juli 2015, disetujui 2 Agustus 2015
Tahun 2008, World Bank (2012) melaporkan bahwa setengah dari penduduk dunia tinggal di daerah perkotaan, dua pertiganya berada di negara-negara berpendapatan menengah dan rendah. Banyaknya jumlah penduduk perkotaan tersebut diperkirakan akan meningkat $60 \%$ pada tahun 2030 , dan $70 \%$ pada tahun 2050 sehingga diproyeksikan akan mencapai 6,2 miliyar atau dua kali lipat dari proyeksi jumlah penduduk pedesaan (World Bank, 2012). Kondisi serupa juga terjadi di Indonesia, seperti yang dilaporkan oleh Dinas Pekerjaan Umum pada tahun 2012 dalam Mulyana, dkk. (2013) yang memperkirakan pertambahan jumlah penduduk di Kawasan Strategis Nasional (KSN) Kedung Sepur sekitar 1,4\% setiap tahunnya. Diperkirakan pada tahun 2030, populasi masyarakat Kedung Sepur mencapai 7.156.000 jiwa, dan 36\% penduduknya akan tinggal di Kota Semarang. Menjadi persoalan dikemudian hari, yaitu pesatnya pertumbuhan penduduk ternyata bersamaan dengan persoalan ekologi kota. Sehingga, diperkirakan bahwa pertumbuhan kota yang 
ditandai oleh pertambahan penduduk mengarah pada kondisi yang rentan, begitupula di Kota Semarang.

Persoalan ekologi di Kota Semarang menghasilkan banyak upaya untuk mempelajari dan menyelesaikannya melalui penelitian yang dilakukan oleh Marfai dan King (2008), Dewi (2007), Sariffuddin dan Wijaya (2014) dan yang terbaru dilakukan oleh Suripin, Helmi, dan Suhardjono (2015). Marfai dan King (2008) menjelaskan bahwa Kota Semarang sebagai kota yang berbatasan dengan laut mengalami tiga jenis banjir yang berbeda, yaitu banjir lokal, banjir kiriman, serta banjir rob. Dari sudut pandang sosial ekonomi, Dewi (2007) menjelaskan bahwa perilaku masyarakat terhadap banjir dipengaruhi oleh beberapa faktor seperti besaran banjir (luas banjir, ketinggian banjir serta durasi banjir) dan kapasitas mereka, dalam hal ini kapasitas ekonomi untuk mengatasi dampaknya. Disamping itu, Dewi (2007) juga berpendapat bahwa informasi tentang kearifan lokal masyarakat sangat penting dan berguna bagi perencana dan pengambil kebijakan untuk merumuskan bentuk adaptasi yang tepat dan layak diterapkan. Sedangkan Sariffuddin dan Wijaya (2014) berpendapat bahwa permasalahan kerentanan sangat berkaitan dengan persoalan ekonomi. Berbeda halnya dengan Suripin, dkk. (2015) yang menganalisis berdasarkan sudut pandang hidrologi yang menyimpulkan bahwa area genangan banjir di Kota Semarang akan meningkat sekitar 8-30\% akibat meningkatnya suhu udara dan adanya perubahan pada karakteristik hujan (curah hujan harian dan intensitas hujan).

Kompleksnya persoalan ekologi kota, malahirkan banyak peneliti yang menghubungkan ketahanan dengan kerentanan. Ketahanan merupakan kapasitas individu, masyarakat atau lembaga untuk menanggapi pergeseran iklim secara dinamis dan efektif hingga pada tingkatan yang dapat diterima. Hal ini mencakup kemampuan untuk menolak atau menahan dampak, serta kemampuan untuk memulihkan atau mengatur kembali sistem agar dapat berkembang dengan lebih baik (Brown, Dayal, \& Del Rio, 2012). Sedangkan kerentanan adalah derajat kemampuan suatu sistem atau bagian dari sistem untuk dapat bereaksi dengan peristiwa yang berbahaya (Usamah, Handmer, Mitchell, \& Ahmed, 2014). Sebagian besar peneliti melihat katahanan sebagai kebalikan dari kerentanan, seperti yang diungkapkan Cutter dalam Usamah, dkk. (2014) menjelaskan bahwa ketahanan adalah faktor kerentanan dan mereka berpotongan konsep. Sedangkan Manyena dalam Usamah, dkk. (2014), berpendapat bahwa kerentanan dan ketahanan mirip dua sisi mata uang yang sama. Berdasarkan pernyataan Cutter dan Manyena di atas, menunjukkan bahwa penilaian tingkat kerentanan kota menjadi penting karena dapat menjadi tolak ukur pencapaian kota tangguh.

Penelitian mengenai tingkat kerentanan sebelumnya telah dilakukan oleh Mulyana, dkk. (2013) dalam upaya mewujudkan Kota Semarang sebagai kota tangguh, yang dilihat dari bencana banjir dan tanah longsor. Penelitian tersebut mengelompokkan beberapa desa di Kota Semarang ke dalam kelompok kerentanan rendah hingga tinggi. Berdasarkan hasilnya, penilaian kerentanan yang dilakukan oleh Mulyana, dkk. (2013) merupakan penilaian kerentanan secara keruangan. Pada dasarnya, penilaian kerentanan dapat dibedakan secara keruangan maupun komunitas/individu. Berkaitan dengan sistem yang terkena dampak terbesar akibat bencana adalah masyarakat, maka perlu dilakukan upaya-upaya untuk meningkatkan kesadaran dan kapasitas masyarakat dalam mengantisipasi bencana yang terjadi di wilayahnya, sehingga resiko bencana dapat dikurangi, dicegah atau bahkan dihilangkan (Kementerian Pekerjaan Umum). Oleh karena itu, penilaian kerentanan secara komunitas/individu dilakukan pada penelitian ini untuk mengetahui tingkat kerentanan masyarakat di Perumnas Tlogosari sehingga masyarakat dapat berketahanan dalam menghadapi bahaya maupun bencana. Seseorang atau komunitas yang berketahanan terhadap bahaya, lebih berpotensi untuk menangkis bahaya menjadi bencana. Apabila bencana sudah terjadi, maka mereka dapat dengan mudah bangkit dari bencana, dan bahaya yang terjadi tidak menjadi ancaman yang berarti (Ghafur, Noorkamilah, \& Gazali, 2012).

Penilaian tingkat kerentanan tidak hanya dibedakan berdasarkan objek yang dinilai, namun juga dapat dibedakan berdasarkan waktu. Wood, Good, dan Goodwin (2002) mengungkapkan bahwa tipe masyarakat yang terkena dampak bencana pada saat siang dan malam berbeda, karena ada perbedaan jumlah masyarakat yang berada di rumah. Pada saat siang, ibu rumah tangga, anakanak dan lansia yang berada di rumah memiliki tingkat kerentanan yang lebih tinggi. Seperti yang diungkapkan oleh Ghafur, dkk. (2012) bahwa perempuan cenderung lebih rentan terhadap bencana dan seringkali diabaikan dalam 
penanganan bencana dibandingkan dengan lakilaki. Hal tersebut menjadi dasar bahwa penilaian tingkat kerentanan masyarakat di Perumnas Tlogosari dapat dibedakan menjadi penilaian kerentanan siang dan malam.

Menurut IPCC (2001), komponen pembentuk kerentanan terdiri dari tiga faktor utama, yaitu keterpaparan (exposure), sensitivitas (sensitivity) dan kemampuan adaptasi (adaptive capacity). Keterpaparan menunjukkan derajat atau besarnya peluang suatu sistem untuk kontak dengan gangguan. Sensitivitas adalah kondisi internal suatu sistem yang menunjukkan tingkat kerawanannya terhadap gangguan, sedangkan kapasitas adaptasi adalah potensi atau kemampuan sistem, wilayah atau masyarakat untuk beradaptasi dengan efek atau dampak yang timbul dari bencana.

Perumnas Tlogosari merupakan salah satu permukiman di Kota Semarang yang terdampak oleh masalah ekologi, yaitu banjir yang terjadi disetiap tahunnya. Penilaian tingkat kerentanan masyarakat di Perumnas Tlogosari dilakukan untuk mengetahui tindakan adaptasi yang tepat, sehingga resiko yang diterima dapat berkurang. Luas perumahan ini sebesar $\pm 170,746$ Ha dan meliputi dua kelurahan yaitu Kelurahan Tlogosari Kulon dan Kelurahan Muktiharjo Kidul. Banjir yang terjadi, membawa dampak yang merugikan bagi masyarakat baik dampak fisik, sosial, ekonomi maupun lingkungan. Untuk lokasi wilayah studi penelitian, dapat dilihat pada gambar 1.

\section{Bencana Perkotaan dan Kerentanan}

Banjir merupakan salah satu permasalahan umum yang sering melanda di kawasan perkotaan. Permasalahan banjir di perkotaan menjadi tantangan yang serius, karena dengan kepadatan penduduk yang tinggi dan aset yang lebih besar berada di kawasan perkotaan, maka kerugian yang ditimbulkan juga besar (World Bank, 2012). Banjir adalah suatu keadaan dimana aliran air yang tidak tertampung oleh palung sungai (PIBA, 2014). Namun, menurut BAKORNAS PB (2007) pengertian banjir dapat dibedakan menjadi dua macam, sehingga pengertian banjir tidak hanya sebatas aliran air sungai yang tingginya melebihi muka air sungai, sehingga tidak tertampung oleh palung dan menyebabkan adanya genangan disisi sungai yang lebih rendah saja. Banjir juga merupakan gelombang banjir yang berjalan kearah hilir sistem sungai yang berinteraksi dengan kenaikan muka air dimuara akibat badai.

Marfai dan King (2008) menjelaskan bahwa Kota Semarang sebagai kota yang berbatasan langsung dengan laut, menghadapi tiga jenis banjir yang berbeda yaitu banjir lokal, banjir kiriman dan banjir rob. Masing-masing pengertian dari ketiga jenis banjir tersebut adalah: (1) Banjir lokal merupakan banjir yang terjadi karena minimnya jumlah dan kualitas sistem drainase di daerah permukiman terutama di kawasan dataran rendah dan pesisir Kota Semarang; (2) Banjir kiriman adalah aliran banjir yang datang dari arah hulu, akibat hujan dengan intensitas tinggi sehingga menimbulkan aliran yang melebihi kapasitas sungai, dan menggenangi kawasan yang berada di hilir sungai (Wismarini \& Ningsih, 2010); dan (3) Banjir rob adalah banjir yang terjadi akibat aliran langsung air pasang dan/atau aliran balik dari saluran drainase akibat terhambat oleh air pasang (Wismarini \& Ningsih, 2010).

\section{Kerentanan}

Kerentanan merupakan suatu kondisi masyarakat yang mengarah atau menyebabkan ketidakmampuan dalam menghadapi ancaman bahaya (BAKORNAS PB, 2007). Menurut IPCC (2001), komponen pembentuk kerentanan terdiri dari tiga faktor, yaitu tingkat keterpaparan (exposure), tingkat sensitivitas (sensitivity) dan kemampuan adaptasi (adaptive capacity). Penjelasan dari masing-masing faktor kerentanan adalah:

Tingkat Keterpaparan (Exposure) menunjukkan derajat atau besarnya peluang suatu sistem untuk kontak dengan gangguan (Adger dan Kasperson, dalam Boer, dkk. (2013)). Menurut Boer, dkk. (2013) tingkat keterpaparan dapat diidentifikasi melalui data tentang topografi dan kemiringan untuk menggambarkan kondisi eksisting, atau besar peluang fasilitas infrastruktur, permukiman dan sumber kehidupan dari lokasi bencana seperti garis pantai (rob), tebing (longsor) dan cekungan (banjir). Penggunaan data geospasial untuk mengukur nilai indikator keterpaparan sangat penting. 


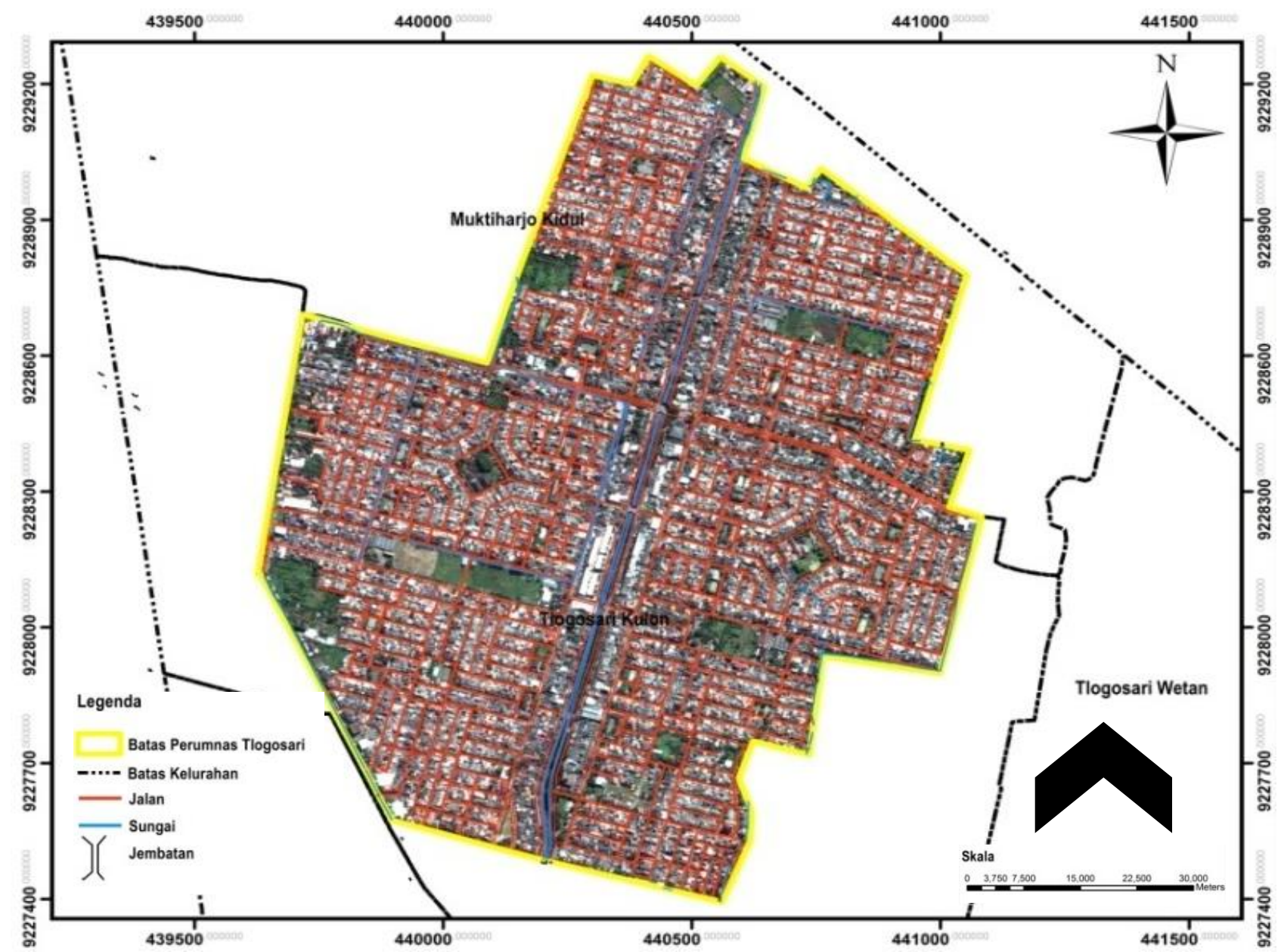

Gambar 1. Lokasi wilayah studi perumnas tlogosari

Tingkat Sensitivitas (Sensitivity) adalah kondisi internal suatu sistem yang menunjukkan tingkat kerawanannya terhadap gangguan (IPCC, 2001). Contoh data untuk mengidentifikasi tingkat sensitivitas adalah akses masyarakat terhadap air bersih, serta laju produksi sampah dan kemampuan pengelolaannya (Boer, dkk., 2013).

Kapasitas Adaptasi (Adaptive Capacity) adalah potensi atau kemampuan sistem, wilayah atau masyarakat untuk beradaptasi dengan efek atau dampak yang timbul dari perubahan iklim (IPCC, 2001). Boer, dkk. (2013) berpendapat bahwa tingkat pendapatan per kapita serta keberadaan dan kekuatan kelembagaan masyarakat, dapat menjadi indikator yang lebih efektif dalam menunjukkan kemampuan adaptasi suatu sistem.

\section{METODE PENELITIAN}

Pendekatan yang digunakan pada penelitian ini adalah pendekatan deduktif dengan metode kuantitatif. Penelitian kuantitatif memusatkan pada gejala-gejala yang mempunyai karakteristik tertentu di dalam kehidupan manusia yang disebut variabel. Variabel yang digunakan untuk menilai tingkat kerentanan dikelompokkan berdasarkan aspek fisik, aspek sosial dan aspek ekonomi di setiap komponen pembentuknya. Pada komponen tingkat keterpaparan variabelnya terdiri dari kondisi jaringan jalan, kondisi jaringan drainase, keberadaan ruang terbuka, keberadaan lembaga kemasyarakatan, serta jumlah keluarga miskin. Untuk tingkat sensitivitas memiliki variabel yang terdiri dari koefisien dasar bangunan (KDB), sarana pengelolaan sampah, ketersediaan sumber air bersih, jumlah anggota keluarga (siang dan malam), jumlah anggota keluarga perempuan (siang dan malam), jumlah anggota keluarga berusia tua dan balita (siang dan malam), status pekerjaan, serta jumlah anggota keluarga yang produktif. Sedangkan variabel pada kapasitas adaptasi terdiri dari keberadaan teknologi lokal, pengetahuan 
masyarakat terhadap bencana, dan kesejahteraan penduduk.

Teknik pengumpulan data terbagi menjadi dua yaitu data primer dan data sekunder. Pada penelitian ini teknik sampling yang digunakan adalah proportional random sampling atau pengambilan sampel dari setiap wilayah yang ditentukan dengan jumlah yang seimbang pada masing-masing wilayah. Hasil dari teknik sampling ini terpilih 122 KK yang menjadi responden, dengan kriteria responden merupakan masyarakat yang berusia produktif. Untuk jumlah responden pada setiap RT yang terpilih, dapat dilihat pada tabel 1 di bawah ini.

Tabel 1

Jumlah sampel per RT

\begin{tabular}{ccc}
\hline RW/RT & Jumlah KK / RT & Jumlah Sampel \\
\hline RW 08/RT 03 & 44 & 9 \\
\hline RW 08/RT 06 & 46 & 10 \\
\hline RW 10/RT 03 & 31 & 6 \\
\hline RW 10/RT 04 & 32 & 7 \\
\hline RW 11/RT 02 & 37 & 8 \\
\hline RW 11/RT 04 & 46 & 10 \\
\hline RW 21/RT 02 & 28 & 6 \\
\hline RW 21/RT 07 & 40 & 8 \\
\hline RW 03/RT 08 & 43 & 9 \\
\hline RW 03/RT 10 & 25 & 5 \\
\hline RW 05/RT 02 & 39 & 8 \\
\hline RW 05/RT 08 & 20 & 4 \\
\hline RW 07/RT 05 & 37 & 8 \\
\hline RW 07/RT 06 & 33 & 7 \\
\hline RW 19/RT 06 & 38 & 8 \\
\hline RW 19/RT 08 & 44 & 9 \\
\hline JUMLAH & 583 & 122 \\
\hline
\end{tabular}

Teknik analisis yang digunakan adalah skoring pembobotan. Variabel kerentanan terpilih, akan diukur dengan memberikan skor menggunakan skala likert. Skor dikelompokkan menjadi lima kategori, dengan nilai -2 hingga 2. Setelah dilakukan skoring, maka tiap-tiap varibel kerentanan akan diberi bobot. Untuk variabel komponen keterpaparan dan sensitivitas, bobot diberikan dengan mempertimbangkan dampak yang dihasilkan, dimana dampak yang mempengaruhi keselamatan jiwa manusia memiliki bobot lebih tinggi dibandingkan dampak yang mempengaruhi materi atau harta benda (Ristianto, 2011). Sedangkan variabel pada komponen kapasitas adaptasi, faktor ekonomi memiliki bobot yang lebih tinggi karena faktor ekonomi merupakan faktor yang paling dominan dalam mempengaruhi bentuk adaptasi yang dilakukan oleh masyarakat (Sariffuddin \& Wijaya, 2014).

Hasil perkalian antara skor dan bobot pada variabel tingkat keterpaparan dan tingkat sensitivitas merupakan Indeks Keterpaparan dan Sensitivitas (IKS), sedangkan hasil perkalian antara skor dan bobot pada variabel kapasitas adaptasi merupakan Indeks Kapasitas Adaptif (IKA). IKS dan IKA yang didapatkan (lihat gambar 2), akan dikelompokkan menggunakan matrik tipologi kerentanan seperti pada gambar 3, sehingga didapatkan Indeks Kerentanan masyarakat di Perumnas Tlogosari. Tipologi kerentanan yang dihasilkan, akan dibedakan menjadi tipologi kerentanan pada saat siang dan malam. Hal ini dilakukan karena karakteristik masyarakat pada saat siang dan malam berbeda, terutama pada jumlah anggota keluarga, jumlah anggota keluarga perempuan serta jumlah anggota keluarga berusia tua dan balita yang berada di rumah.

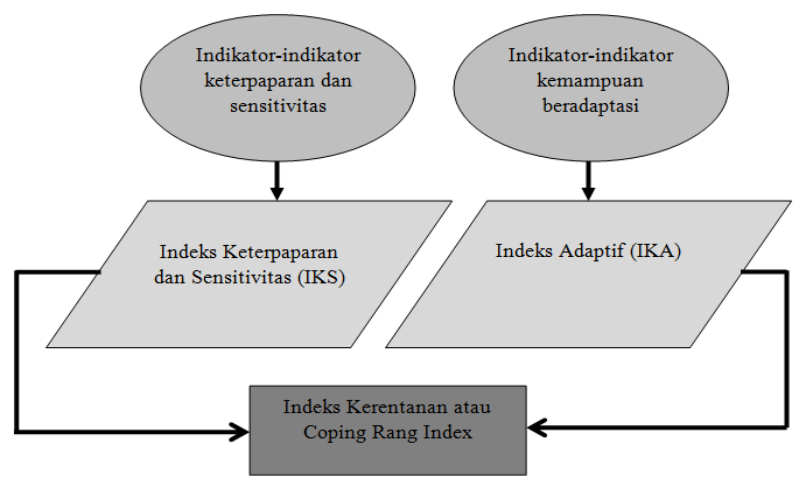

Gambar 2. Konsep indek kerentanan (Sumber: Boer (2012))

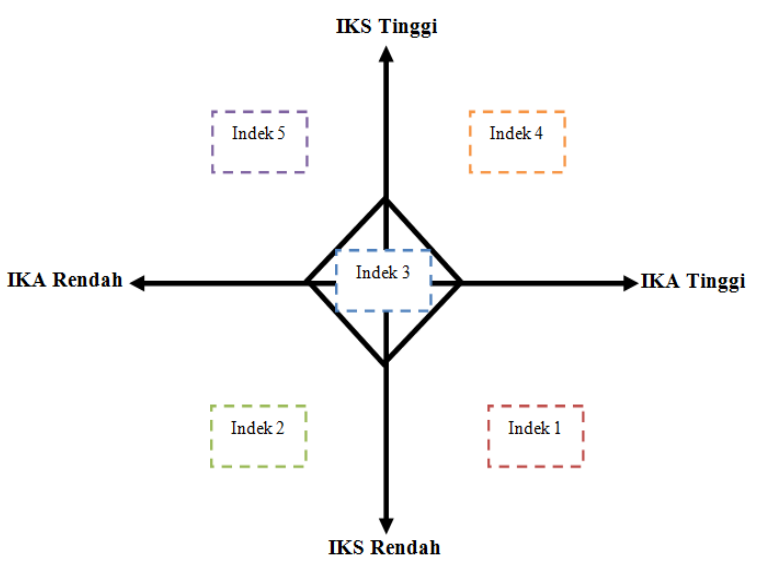

Gambar 3. Tipologi kerentanan (Sumber: Boer (2012)) 
Keterangan:

Indek 5 : Sangat Rentan;

Indek 4 : Rentan;

Indek 3 : Agak Rentan;

Indek 2 : Kurang Rentan; dan

Indek 1 : Tidak Rentan.

\section{HASIL DAN PEMBAHASAN}

Matrik tipologi kerentanan masyarakat di Perumnas Tlogosari menunjukkan bahwa kerentanan siang dan kerentanan malam memiliki perbedaan. Pada saat siang hari, masyarakat memiliki tingkat kerentanan yang lebih tinggi dibandingkan pada saat malam. Hal ini ditandai dengan peningkatan jumlah masyarakat yang berada di kuadran 1 dan 2 pada saat malam, dan diikuti oleh penurunan jumlah masyarakat yang berada di kuadran 3 dan 5 . Prosentase penurunan dan peningkatan jumlah masyarakat tersebut sebesar 2-3\%.

Sebagian besar masyarakat berada di kuadaran 2 yang mengartikan bahwa masyarakat kurang rentan dalam menghadapi banjir yang terjadi. Prosentase masyarakat yang berada di kuadran 2 pada saat siang sebesar $44 \%$, sedangkan pada saat malam sebesar $46 \%$. Untuk jumlah masyarakat yang terkecil, berada di kuadran 5 yang mengartikan bahwa masyarakat sangat rentan dalam menghadapi banjir. Prosentase masyarakat yang berada di kuadran 5 pada saat siang sebesar 2\%, sedangkan pada saat malam tidak ada masyarakat yang berada di kuadran tersebut. Penjelasan lebih lanjut tentang jumlah masyarakat yang berada di masing-masing kuadran kerentanan siang dan malam, dapat dilihat pada gambar 4 berikut ini.

$$
\text { Kerentanan Siang }
$$

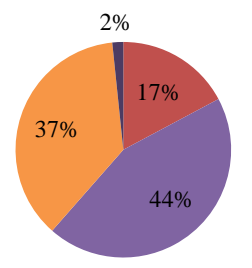

Kerentanan Malam
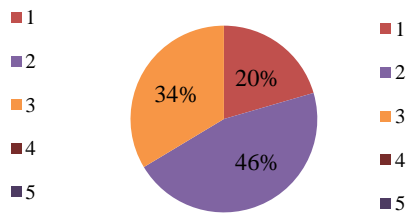

Gambar 4. Prosentase masyarakat pada masingmasing kuadran

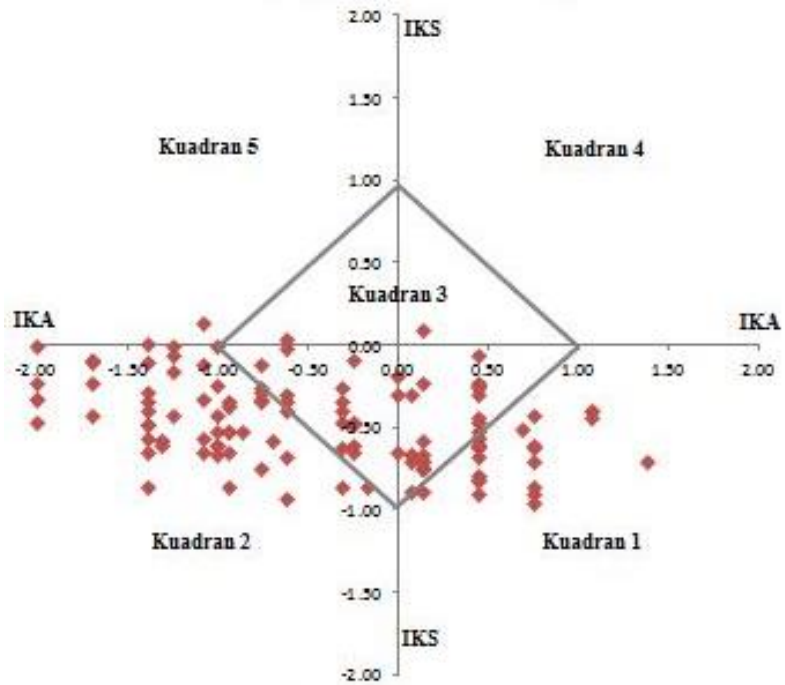

Gambar 5. Tipologi Kerentanan siang Masyarakat di Perumnas Tlogosari

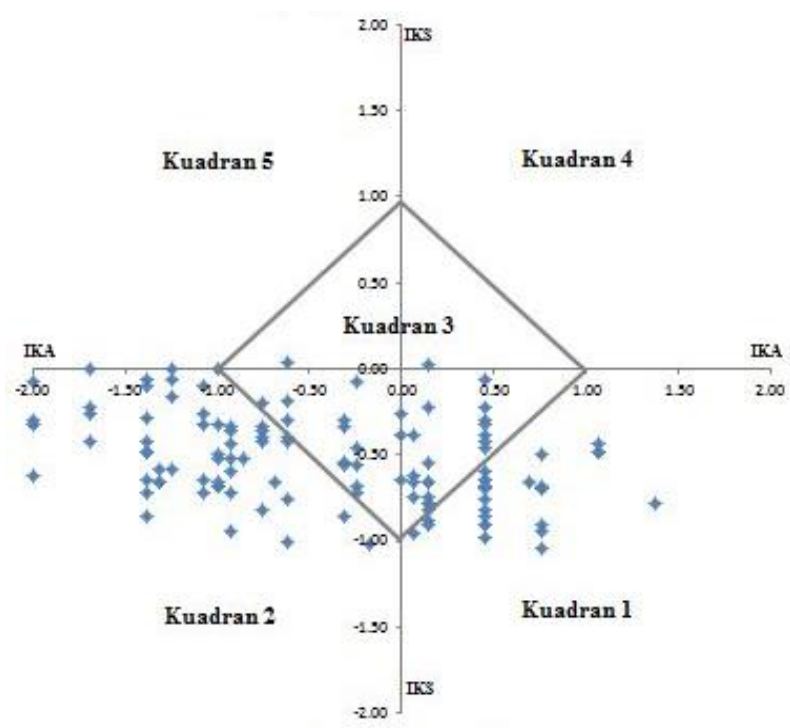

Gambar 6. Tipologi Kerentanan Malam Masyarakat di Perumnas Tlogosari

Gambar 5 dan gambar 6 di atas menunjukkan tipologi kerentanan masyarakat di waktu siang dan malam. Apabila dilihat secara keseluruhan, masyarakat yang berada pada kuadran 1, 2 dan 3 lebih banyak dibandingkan dengan yang berada pada kuadran 5. Masyarakat yang berada diketiga kuadran tersebut merupakan masyarakat yang belum rentan atau masyarakat masih berada pada selang toleransi kemampuan mereka untuk menghadapi banjir yang terjadi. Apabila tidak dilakukan intervensi dengan melakukan bentuk adaptasi yang tepat, maka masyarakat yang berada 
di kuadran 1, 2, dan 3 dapat berubah menjadi masyarakat yang rentan bahkan sangat rentan.

Terdapat beberapa variabel yang memiliki hasil perkalian skoring dengan bobot paling tinggi pada kerentanan siang dan malam masyarakat. Pada komponen keterpaparan, variabel yang mempengaruhi kerentanan siang dan malam, yaitu kondisi jaringan drainase. Kondisi jaringan drainase memiliki skor dan bobot yang cukup tinggi, mengingat bahwa banjir yang terjadi merupakan banjir lokal yang diakibatkan karena kualitas dan kuantitas drainase, baik drainase primer (Sungai Tenggang) maupun drainase lingkungan yang buruk.

Pada komponen sensitivitas, variabel yang memiliki hasil perkalian skor dan bobot tertinggi berbeda pada kerentanan siang dan malam. Pada kerentanan siang, variabel yang hasil perkalian skor dan bobotnya tinggi adalah jumlah anggota keluarga yang berada di rumah pada saat siang hari. Sedangkan pada kerentanan malam, adalah koefisien dasar bangunan (KDB). Untuk kapasitas adaptasi masyarakat, variabel yang paling berpengaruh pada kerentanan siang dan malam, yaitu kesejahteraan masyarakat. Kesejahteraan masyarakat Perumnas Tlogosari tinggi, karena termasuk ke dalam golongan menengah ke atas dan setiap bulannya masyarakat dapat menyisakan pendapatan yang dihasilkan untuk kebutuhan yang tidak terduga. Penjelasan lebih lanjut tentang masing-masing variabel yang paling berpengaruh terhadap tingkat keterpaparan, sensitivitas dan kapasitas adaptasi adalah sebagai berikut:

Kondisi Jaringan Drainase di Perumnas Tlogosari belum optimal, hal ini ditandai dengan adanya permasalahan dari segi teknis maupun sistem. Permasalahan teknis pada jaringan drainase meliputi kondisi drainase yang sempit, dangkal dan tidak lancar mengalirkan air akibat banyaknya sampah yang menyumbat. Untuk permasalahan sistem yang ada berupa tidak terintegrasinya jaringan drainase, akibat penutupan salah satu jaringan yang disebabkan oleh pelebaran jalan. Penjelasan lebih lanjut tentang kondisi jaringan drainase di Perumnas Tlogosari, dapat dilihat pada tabel 2.
Tabel 2

Kondisi Jaringan Drainase di Perumnas Tlogosari

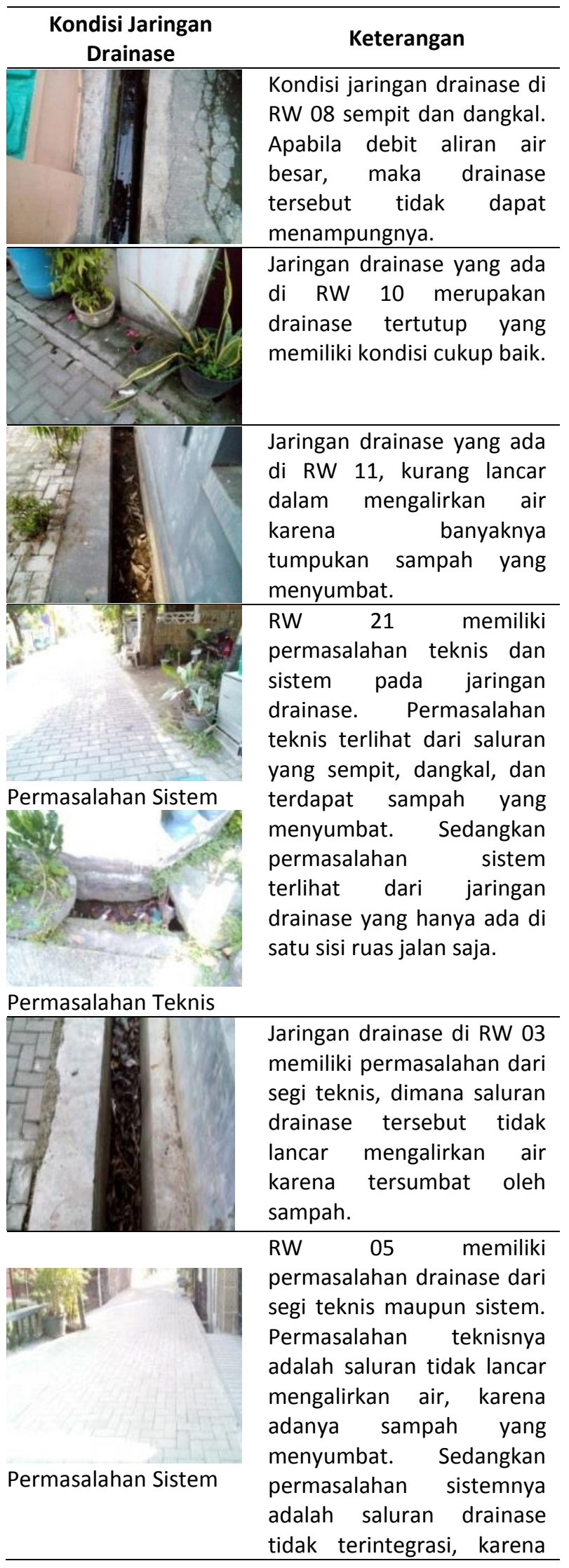




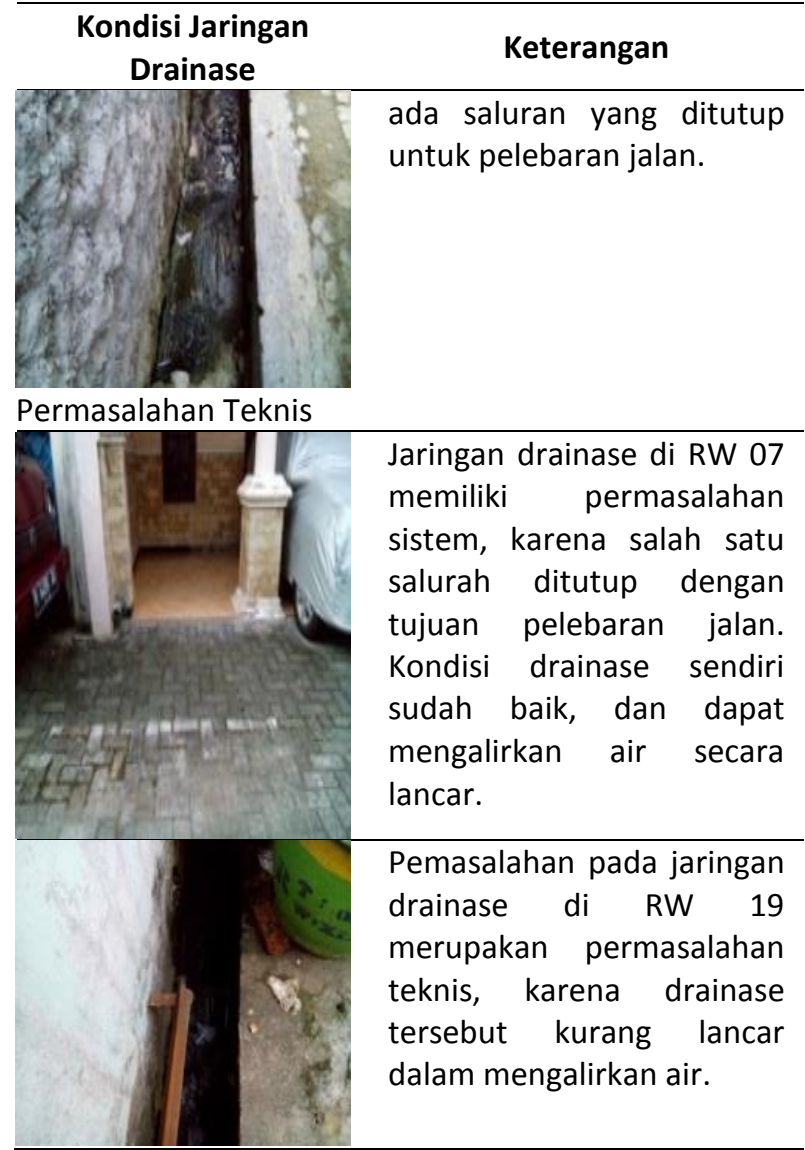

Drainase yang memiliki permasalahan teknis dan sistem, memiliki skor yang lebih tinggi dibandingkan dengan drainase yang memiliki permasalahan dari segi teknis maupun sistem saja. Namun, permasalahan sistem pada drainase memiliki skor lebih tinggi dibandingkan dengan permasalahan teknis. Hal ini dikarenakan permasalahan teknis lebih mudah untuk diselesaikan dengan cara kerjabakti, normalisasi drainase dan lain sebagainya. Sedangkan permasalahan sistem yang tidak terintegrasi mengakibatkan aliran air tidak sampai ke muara sungai, sehingga menyebabkan masyarakat terpapar oleh genangan banjir.

Jumlah Anggota Keluarga pada saat siang lebih sedikit dibandingkan pada saat malam, karena masyarakat banyak yang melakukan aktivitas di luar rumah pada saat siang hari (lihat gambar 7). Hasil survei menunjukkan bahwa pada saat siang, $65 \%$ masyarakat yang berada di rumah berjumlah 1-2 orang dan $12 \%$ menunjukkan bahwa tidak ada anggota keluarga yang berada di rumah. Namun, pada saat malam prosentase terbesar yaitu $53 \%$ menunjukkan bahwa jumlah anggota keluarga yang berada di rumah sebesar 3-4 orang. Kondisi ini menjadikan tingkat sensitivitas masyarakat pada saat siang lebih tinggi dibandingkan pada saat malam. Tingkat sensitivitas masyarakat akan semakin tinggi apabila yang berada di rumah merupakan anggota keluarga berusia balita, lansia dan perempuan.
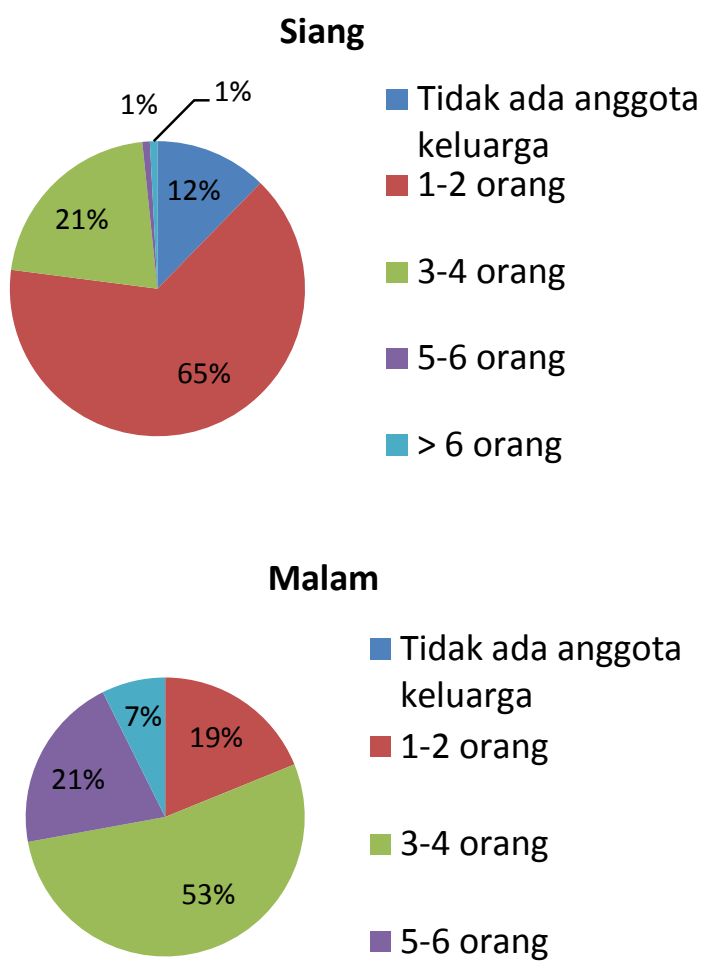

Gambar 7. Prosentase jumlah anggota keluarga saat siang dan malam

Koefisien Dasar Bangunan (KDB) menurut Peraturan Daerah Kota Semarang No 10 Tahun 2004 Tentang Rencana Detail Tata Ruang Kota (RDTRK) Kota Semarang Bagian Wilayah Kota V (Kecamatan Gayamsari dan Kecamatan Pedurungan) Tahun 2000-2010 disebutkan bahwa rencana KDB yang ditetapkan untuk kawasan perumahan sebesar $60 \%$. Hasil survei menunjukkan bahwa sebesar $97 \%$ masyarakat memiliki rumah dengan KDB lebih dari $60 \%, 2 \%$ masyarakat memiliki rumah dengan KDB $60 \%$, serta $1 \%$ sisanya memiliki rumah dengan KDB kurang dari $60 \%$. Banyaknya masyarakat yang melanggar ketentuan KDB tersebut, menjadikan tingkat sensitivitas dalam menghadapi banjir lebih tinggi karena air hujan yang jatuh akan dibebankan kepada saluran drainase, dan tidak ada yang diresapkan ke dalam tanah. Penjelasan lebih lanjut tentang prosentase KDB masyarakat, dapat dilihat pada gambar 8. 


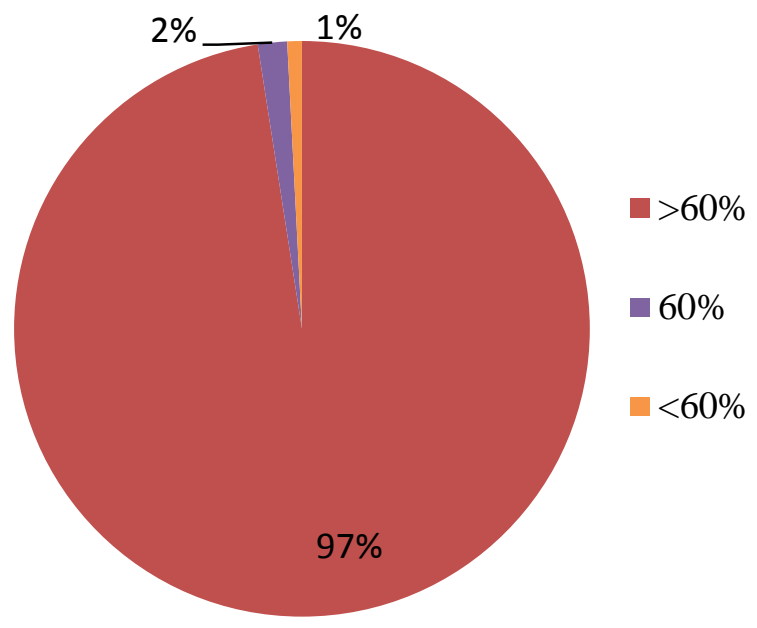

Gambar 8. Prosentase KDB rumah masyarakat

Kesejahteraan Masyarakat dapat dilihat dari kemampuan masyarakat untuk menyisakan pendapatan yang dihasilkan. Hasil kuisioner menunjukkan bahwa sebesar $75 \%$ masyarakat sudah dapat menyisakan pendapatan yang dihasilkan, dengan prosentase terbesar yaitu $34 \%$ masyarakat dapat menyisakan > Rp 450.000,- per bulannya (lihat gambar 9). Masyarakat yang sudah mampu menyisakan pendapatan yang dihasilkan memiliki skor yang lebih tinggi dibandingkan dengan masyarakat yang belum bisa menyisakan pendapatannya, karena kapasitas adaptasi yang dimiliki juga lebih tinggi dalam menghadapi kondisi yang tidak terduga akibat bencana banjir yang terjadi.

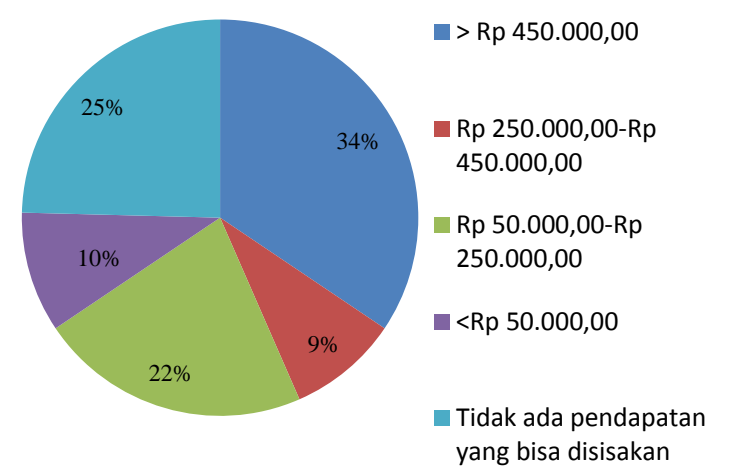

Gambar 9. Prosentase kesejahteraan masyarakat

\section{KESIMPULAN}

Permasalahan banjir yang terjadi setiap tahun, tidak membuat masyarakat di Perumnas Tlogosari rentan dalam menghadapinya. Hal ini dibuktikan dengan tingginya prosentase masyarakat yang berada di kuadran 2, yaitu sebesar $44 \%$ pada kerentanan siang dan $46 \%$ pada kerentanan malam. Antara tingkat kerentanan siang dan malam pun memiliki perbedaan, dimana pada saat siang hari masyarakat memiliki kerentanan yang lebih tinggi dibandingkan pada saat malam. Secara keseluruhan, jumlah masyarakat yang berada di kuadran 1, 2 dan 3 lebih banyak dibandingkan dengan masyarakat yang berada di kuadran 5 . Oleh karena itu, sebagian besar masyarakat di Perumnas Tlogosari masih berada pada selang toleransi/ batas kemampuan mereka untuk menghadapi banjir yang terjadi atau masyarakat telah menjadi masyarakat yang berketahanan dalam menghadapi banjir.

Masing-masing komponen pembentuk kerentanan dipengaruhi oleh beberapa variabel yang memiliki hasil perkalian skor dengan bobot tertinggi, diantaranya kondisi jaringan drainase, jumlah anggota keluarga pada saat siang, Koefisien Dasar Bangunan (KDB) serta kesejahteraan penduduk. Kondisi jaringan drainase yang belum optimal, sedikitnya jumlah anggota keluarga yang berada di rumah saat siang hari, serta banyaknya masyarakat yang melanggar ketentuan KDB yang telah ditetapkan, menjadikan hasil skoring pembobotan tinggi sehingga berpengaruh terhadap tingginya Indek Keterpaparan dan Sensitivitas (IKS). Disamping itu, tingginya kesejahteraan masyarakat berpengaruh terhadap Indek Kapasitas Adaptasi (IKA).

Penilaian tingkat kerentanan yang dilakukan hanya berlandaskan pada aspek fisik, sosial dan ekonomi saja. Hal ini menjadi suatu kekurangan penelitian yang belum memperhatikan kebijakan pemerintah. Penilaian kerentanan ini juga hanya menilai kerentanan rumah tangga saja, dan mengabaikan kerentanan komunitas.

Tingkat kerentanan dapat menjadi acuan normatif bagi masyarakat maupun pemerintah untuk melakukan adaptasi yang tepat. Dengan teridentifikasinya kerentanan, masyarakat maupun pemerintah dapat mengetahui faktor-faktor apa saja yang mempengaruhi tingginya tingkat keterpaparan, sensitivitas dan kapasitas adaptasi. Sehingga bentuk adaptasi yang dilakukan masyarakat ataupun perumusan kebijakan pemerintah terkait bentuk adaptasi, tepat dan layak untuk diterapkan. 
Pentingnya meningkatkan kapasitas adaptasi masyarakat yang berada di rumah pada saat siang hari, seperti ibu rumah tangga. Peningkatan tersebut dapat dilakukan dengan cara pengadaan penyuluhan maupun sosialisasi mengenai tanggap darurat bencana.

\section{DAFTAR PUSTAKA}

Abdoullaev, A. (2011). A smart world: A development model for intelligent cities. Paper presented at the The 11th IEEE International Conference on Computer and Information Technology.

BAKORNAS PB. (2007). Pengenalan Karakteristik Bencana dan Upaya Mitigasinya di Indonesia. Badan Koordinasi Nasional Penanggulangan Bencana, Jakarta.

Boer, R. (2012). Analisis penilaian tingkat kerentanan. Pelatihan Aplikasi Metode Kerentanan. CCROMSEAP IPB. Bogor.

Boer, R., Faqih, A., Ardiansyah, M., Kolopaking, L., Rakhman, A., Nurbaeti, B., ... Anria, A. (2013). RENCANA AKSI MITIGASI DAN ADAPTASI PERUBAHAN IKLIM DALAM KERANGKA PENGELOLAAN SUMBERDAYA AIR DI DAS CITARUM DI KABUPATEN BANDUNG BARAT.

Brown, A., Dayal, A., \& Del Rio, C. R. (2012). From practice to theory: emerging lessons from Asia for building urban climate change resilience. Environment and Urbanization, 24(2).

Dewi, A. (2007). Community-Based Analysis of Coping With Urban Flooding : A Case Study in Semarang, Indonesia. (Master), International Institue For Geo-Information Science and Earth Observation Enschede, Netherlands.

Ghafur, W. A., Noorkamilah, \& Gazali, H. (2012). RESILIENCE PEREMPUAN DALAM BENCANA ALAM MERAPI: STUDI DI KINAHREJO UMBULHARJO CANGKRINGAN SLEMAN YOGYAKARTA (WELFARE JURNAL ILMU KESEJAHTERAAN SOSIAL, VOL. 1, NO. 1, JANUARI-JUNI 2012). WELFARE JURNAL ILMU KESEJAHTERAAN SOSIAL, VOL. 1, NO. 1, JANUARI-JUNI 2012.

IPCC. (2001). Climate change 2001: impacts, adaptation, and vulnerability: contribution of Working Group II to the third assessment report of the Intergovernmental Panel on Climate Change: Cambridge University Press.

Kementerian Pekerjaan Umum. Pedoman Teknis Pengurangan Resiko Bencana Berbasis Komunitas (PRB-BK).
Marfai, M. A., \& King, L. (2008). Coastal flood management in Semarang, Indonesia. Environmental geology, 55(7).

Mulyana, W., Setiono, I., Selzer, A. K., Zhang, S., Dodman, D., \& Schensul, D. (2013). Urbanisation, Demographics, and Adaptation to Climate Change in Seamarang, Indonesia. International Institute For Environment And Development United Nations Populaton Fund(Urbanization and Emerging Population Issues Working aaper 11).

PIBA, P. I. B. A. (2014). Pedoman Penanggulangan Banjir. Retrieved from http://piba.tdmrc.org/content/pedomanpenanggulangan-banjir

Ristianto. (2011). Kerentanan Wilayah Pesisir Terhadap Kenaikan Muka Laut (Studi Kasus Wilayah Pesisir Utara Jawa Barat). (S2), Universitas Indonesia, Depok.

Sariffuddin, \& Wijaya, A. P. (2014). POLA ADAPTASI MASYARAKAT PESISIR GENUK KOTA SEMARANG. Tataloka Jurnal, 16(4).

Suripin, Helmi, M., \& Suhardjono. (2015). The Impacts of Climate Change and Land Subsidence on The Urban Drainage System Development in Semarang City. Prosiding Seminar Nasional Innovation in Environmental Management 2015, 63-68.

Usamah, M., Handmer, J., Mitchell, D., \& Ahmed, I. (2014). Can the vulnerable be resilient? Coexistence of vulnerability and disaster resilience: Informal settlements in the Philippines. International Journal of Disaster Risk Reduction, 10.

Wismarini, T. D., \& Ningsih, D. H. U. (2010). Analisis Sistem Drainase Kota Semarang Berbasis Sistem Informasi Geografi dalam Membantu Pengambilan Keputusan bagi Penanganan Banjir. Dinamik-Jurnal Teknologi Informasi, 15(1).

Wood, N. J., Good, J. W., \& Goodwin, R. F. (2002). Vulnerability assessment of a port and harbor community to earthquake and tsunami hazards: integrating technical expert and stakeholder input. Natural hazards review, 3(4), 148-157.

World Bank. (2012). Kota dan Banjir: Panduan Pengelolaan Terintegrasi untuk Resiko Banjir Perkotaan di Abad 21. Washington DC: The World Bank. 